\title{
Discovery and Evaluation of Polymorphisms in the AKT2 and AKT3 Promoter Regions for Risk of Korean Lung Cancer
}

\author{
Jae Sook Sung ${ }^{1,2}$, Kyong Hwa Park ${ }^{3}$, Seung Tae Kim ${ }^{3}$, Yeul Hong Kim ${ }^{1,2,3 *}$ \\ ${ }^{1}$ Genomic Research Center for Lung and Breast/Ovarian Cancers, Korea University Anam Hospital, Seoul 136-705, Korea, \\ ${ }^{2}$ Division of Brain Korea 21 Program for Biomedical Science, Korea University College of Medicine, Seoul 136-701, Korea, \\ ${ }^{3}$ Division of Oncology/Hematology, Department of Internal Medicine, Korea University Anam Hospital, \\ Korea University College of Medicine, Seoul 136-701, Korea
}

\begin{abstract}
AKT is a signal transduction protein that plays a central role in the tumorigenesis. There are 3 mammalian isoforms of this serine/threonine protein kinase-AKT1, AKT2, and AKT3-showing a broad tissue distribution. We first discovered 2 novel polymorphisms (AKT2 -9826 C/G and AKT3 -811 A/G), and we confirmed 6 known polymorphisms (AKT2 -9473 C/T, AKT2 -9151 C/T, AKT2 -9025 C/T, AKT2 -8618G/A, AKT3 -675 A--, and AKT3 -244 C/T) of the AKT2 and AKT3 promoter region in 24 blood samples of Korean lung cancer patients using direct sequencing. To evaluate the role of $A K T 2$ and $A K T 3$ polymorphisms in the risk of Korean lung cancer, genotypes of the AKT2 and AKT3 polymorphisms (AKT2 -9826 C/G, AKT2 -9473 C/T, AKT2 -9151 C/T, AKT2 -9025 C/T, AKT2 -8618G/A, and AKT3 -675 AV-) were determined in 360 lung cancer patients and 360 normal controls. Statistical analyses revealed that the genotypes and haplotypes in the $A K T 2$ and $A K T 3$ promoter regions were not significantly associated with the risk of lung cancer in the Korean population. These results suggest that polymorphisms of the AKT2 and AKT3 promoter regions do not contribute to the genetic susceptibility to lung cancer in the Korean population.
\end{abstract}

Keywords: AKT, genetic polymorphism, genetic promoter region, lung neoplasms

\section{Introduction}

Lung cancer has been the leading cause of cancer-related deaths in Korea, and its incidence continues to rise [1]. Despite therapeutic advances, the overall 5-year survival remains only $15 \%$ [2]. Lung cancer is a multicellular and multistage process that involves a number of genetic changes in oncogenes and tumor suppressor genes. Nevertheless, the prognosis of lung cancer has remained poor despite innovations in diagnostic testing and surgical technique and the development of new chemotherapeutic agents. Recently introduced targeted agents show different responses according to histological subtype, and the efficiency of treatment modalities for lung cancer depends on the time of diagnosis [3]. Therefore, there is a great need for rapid and efficient early detection methods. For developing improved molecular biomarkers for the early detection and prediction of response to chemotherapy, it is important to identify genetic alterations specific to each subtype of lung cancer. Single-nucleotide polymorphisms (SNPs) represent an important class of genetic variations and affect an individual's susceptibility to disease in certain circumstances [4-6].

Activation of the intracellular survival signal transduction protein $\mathrm{AKT}$, known as protein kinase $\mathrm{B}$, has been proposed as a central signaling event in carcinogenesis and has been shown in experimental models to confer resistance to chemotherapy and radiation $[7,8]$. AKT is activated by phosphatidylinositol 3 phosphates, the products of phosphoinositide 3-kinase (PI3K) activity [9]. Additionally, AKT activity is commonly dysregulated in a variety of human tumors because of frequent inactivation of the PTEN tumor suppressor gene, which negatively regulates phosphatidylinositol 3 phosphate levels, and alterations of this gene have been identified in various cancers, including lung cancer $[10,11]$. To date, 3 human isoforms of $A K T$ have been 
identified, $A K T 1, A K T 2$, and $A K T 3$, which are expressed in lung, breast, colon, and prostate tumor tissues [12].

Somatic mutations of AKTs have been reported in endometrial carcinomas, hypoglycemia, and breast cancer $[13,14]$. However, somatic mutations in AKT families are rare in lung cancer $[15,16]$. Previously, it was reported that an $A K T 1$ polymorphism was not associated with schizophrenia $[17,18]$. AKT1 and AKT2 polymorphisms have been reported to be related to survival of esophageal cancer [19], and it was reported that an AKT1 polymorphism was associated with survival in surgically resected non-small cell lung cancer [20]. However, the association between AKT2 and $A K T 3$ polymorphisms and the risk of lung cancer has not yet been clarified. This study discovered polymorphisms of the AKT2 and AKT3 promoter regions and their relation with the risk of lung cancer in a Korean population.

\section{Methods}

\section{Study subjects}

Between August 2001 and November 2010, blood samples were collected from 720 subjects, including 360 lung cancer patients and 360 normal controls without cancer. Lung cancer patients were recruited from the patient pool at the Genomic Research Center for Lung and Breast/Ovarian Cancer, and control subjects were randomly selected from a pool of healthy volunteers who had visited the Cardiovascular Genome Center and Genomic Research Center for Allergy and Respiratory Diseases. Detailed information on diet, smoking status, drinking status, lifestyle, and medical history were collected by trained interviewers using a structured questionnaire. Out of 360 cases, information was available for 352 on smoking status, 317 on stage, and 343 on cell type, while information was available for 272 on smoking status of 360 controls. All study subjects provided written consent and were ethnic Koreans, and all participating Institutional Review Boards approved the study protocol.

\section{Preparation of genomic DNA and direct sequencing}

Genomic DNA was prepared from peripheral blood samples using a Puregene blood DNA kit (Gentra, Minneapolis, MN, USA), following the manufacturer's protocol.

To identify polymorphisms in the promoter of the AKT2 and AKT3 genes, human genomic DNA was isolated from the whole blood of 24 lung cancer patients for direct sequencing, and the promoter region of the AKT2 and AKT3 genes was amplified. Polymerase chain reaction (PCR) amplifications were performed on a PTC-225 Peltier Thermal cycler (MJ Research Inc., Waltham, MA, USA) using AmpliTagGold (Roche, Branchburg, NJ, USA). All amplifications were performed using 35 cycles of $30 \mathrm{~s}$ at $95^{\circ} \mathrm{C}, 1 \mathrm{~min}$ at $64^{\circ} \mathrm{C}$, and $1 \mathrm{~min}$ at $72^{\circ} \mathrm{C}$, followed by a single $10-\mathrm{min}$ extension at $72^{\circ} \mathrm{C}$. PCR products were purified using the Montage PCR96 Cleanup kit (Millipore, Bedford, MA, USA) and eluted in $20 \mu \mathrm{L}$ of nuclease-free $\mathrm{H}_{2} \mathrm{O}$. DNA cycle sequencing was carried out using the BigDye Terminator $\mathrm{V}$ 3.1 Cycle Sequencing kit (Perkin Elmer, Foster City, CA, USA). Multiscreen SEQ 384-well filter plates were used for dye removal, and sequences were then analyzed on an Applied Biosystems 3700 (ABI, Foster City, CA, USA). All polymorphisms and sequence alignments were analyzed using Polyphred.

\section{Genotyping}

After direct sequencing of the AKT2 and AKT3 genes, we performed genotyping for the 8 polymorphisms of the $A K T 2$ and AKT3 genes. The genotypes of the AKT2 and AKT3 polymorphisms were screened by TaqMan fluorogenic 5 nuclease assay (ABI). The final volume of the PCR was $5 \mu \mathrm{L}$, containing $10 \mathrm{ng}$ of genomic DNA, and $2.5 \mu \mathrm{L}$ TaqMan Universal PCR Master Mix, with $0.13 \mu \mathrm{L}$ of $40 \times$ Assay Mix. Thermal cycle conditions were as follows: $50^{\circ} \mathrm{C}$ for $2 \mathrm{~min}$ to activate uracil $\mathrm{N}$-glycosylase and prevent carryover contamination, $95^{\circ} \mathrm{C}$ for $10 \mathrm{~min}$ to activate the DNA polymerase, and 45 cycles of $95^{\circ} \mathrm{C}$ for $15 \mathrm{~s}$ and $60^{\circ} \mathrm{C}$ for 1 min. All PCRs were performed using 384-well plates on a Dual 384-Well GeneAmp PCR System 9700 (ABI), and the endpoint fluorescent readings were performed on an $\mathrm{ABI}$ PRISM 7900 HT Sequence Detection System (ABI). Duplicate samples and negative controls were included to ensure accuracy of genotyping.

\section{Statistical analysis}

Allele frequencies, genotype frequencies, and departures of genotype distributions from Hardy-Weinberg equilibrium (HWE) for each SNP were analyzed using chi-square test or Fisher's exact test. A p-value of $<0.05$ was considered statistically significant. Linkage disequilibrium (LD) was tested on pairwise combinations of polymorphisms using the absolute value of the standardized measure of LD, D', calculated by Haploview version 3.2. The haplotypes and their frequencies were estimated by Haploview version 3.2. Genotype-specific risks were estimated as odds ratios with associated $95 \%$ confidence intervals by unconditional logistic regression (SAS Institute Inc., Cary, NC, USA) and adjusted for age, gender, and smoking status.

\section{Results}

Table 1 shows the clinicopathological features of cases and controls. All the clinical characteristics, except for smoking 
Table 1. Characteristics of the study subjects

\begin{tabular}{|c|c|c|c|}
\hline Variables & Cases $(\%)$ & Controls $(\%)$ & p-value \\
\hline Age $(y)$ & $60.14 \pm 9.39$ & $60.56 \pm 10.28$ & 0.552 \\
\hline \multicolumn{4}{|l|}{ Gender } \\
\hline Male & $262(72.8)$ & $264(73.3)$ & 0.933 \\
\hline Female & $98(27.2)$ & $96(26.7)$ & \\
\hline \multicolumn{4}{|l|}{ Smoking status } \\
\hline Smoker & $253(71.9)$ & $127(46.7)$ & $<0.001$ \\
\hline Non-smoker & $99(28.1)$ & $145(53.3)$ & \\
\hline \multicolumn{4}{|l|}{ Stage } \\
\hline $1-3 a$ & $76(24.0)$ & & \\
\hline $3 b-4$ & $241(76.0)$ & & \\
\hline \multicolumn{4}{|l|}{ Cell type } \\
\hline $\begin{array}{l}\text { Adenocarcinoma } \\
\text { (Adcc) }\end{array}$ & $148(43.1)$ & & \\
\hline $\begin{array}{l}\text { Squamous } \\
\text { carcinoma (Sqcc) }\end{array}$ & $110(32.1)$ & & \\
\hline Other carcinoma & $85(24.8)$ & & \\
\hline
\end{tabular}

Other carcinomas include small cell, large cell, mixed cell carcinomas, and undifferentiated carcinomas.

Table 2. Polymorphism confirmation of the AKT2 and AKT3 promoter region by direct sequencing

\begin{tabular}{llll}
\hline Gene & SNP location & \multicolumn{1}{c}{ rs no. } & \multicolumn{1}{c}{ Frequency } \\
\hline AKT2 & $-9826 \mathrm{C} / \mathrm{G}$ & Novel & $\mathrm{C}: \mathrm{G}=0.957: 0.043$ \\
& $-9473 \mathrm{C} / \mathrm{T}$ & rs9636120 & $\mathrm{C}: \mathrm{T}=0.636: 0.364$ \\
& $-9151 \mathrm{~T} / \mathrm{C}$ & rs1991823 & $\mathrm{T}: \mathrm{C}=0.543: 0.457$ \\
& $-9025 \mathrm{C} / \mathrm{T}$ & rs4239505 & $\mathrm{C}: \mathrm{T}=0.935: 0.065$ \\
& $-8618 \mathrm{G} / \mathrm{A}$ & rs11669332 & $\mathrm{G}: \mathrm{A}=0.937: 0.063$ \\
AKT3 & $-811 \mathrm{~A} / \mathrm{G}$ & Novel & $\mathrm{A}: \mathrm{G}=0.979: 0.021$ \\
& $-675 \mathrm{~A}-$ & rs35835614 & $\mathrm{A}:-=0.688: 0.312$ \\
& $-244 \mathrm{C} / \mathrm{T}$ & rs12043115 & $\mathrm{C}: \mathrm{T}=0.978: 0.022$ \\
\hline
\end{tabular}

SNP, single-nucleotide polymorphisms.

status, were not significantly different between the cases and controls. This difference of smoking status was controlled in the multiple logistic regression analysis, adjusted for age, gender, and smoking status.

By direct sequencing of the AKT2 promoter region in 24 lung cancer patient samples, we identified 1 novel polymorphism $(-9826 \mathrm{C} / \mathrm{G})$ and 4 known polymorphisms (-9473 $\mathrm{C} / \mathrm{T},-9151 \mathrm{C} / \mathrm{T},-9025 \mathrm{C} / \mathrm{T}$, and $-8618 \mathrm{G} / \mathrm{A})$. Also, we identified 1 novel polymorphism $(-811 \mathrm{~A} / \mathrm{G})$ and 2 known polymorphisms $(-675 \mathrm{~A} /-$ and $-244 \mathrm{C} / \mathrm{T})$ by direct sequencing in the AKT3 promoter region (Table 2). The genotype distributions of the polymorphisms were in HWE. Also, LD and haplotypes in the polymorphisms of $A K T 2$ were calculated. However, the LD and haplotype block in AKT3 polymorphisms were unidentified because of the low frequency of the AKT3-811 G allele and AKT3-244 T allele (2.1\% and $2.2 \%$, respectively) (Fig. 1). Accordingly, we
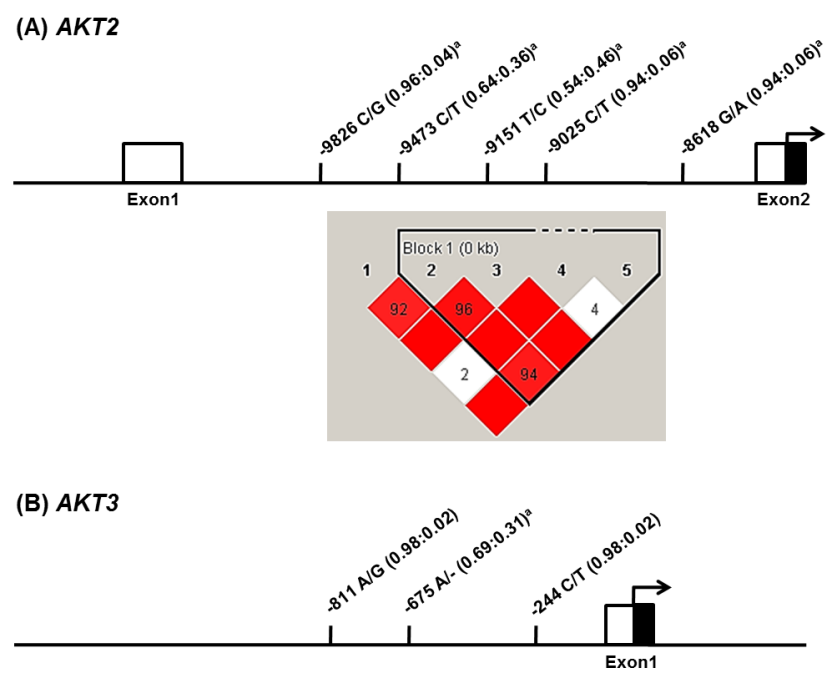

Fig. 1. Polymorphism location in promoter region and linkage disequilibrium (LD). Coding exons are marked by black blocks, and untranslated regions are marked by white blocks. The first base of the translational site is denoted as nucleotide +1 . (A) AKT2 location of promoter polymorphisms and LD block. (B) AKT3 location of promoter polymorphisms. The LD of AKT3 polymorphisms was not identified. ${ }^{a}$ Further analyses polymorphism sites.

focused on the $-675 \mathrm{~A} /$ - polymorphism in the AKT3 promoter region. Further analyses were then performed on the samples from 460 lung cancer patients and 460 controls.

Association of lung cancer risk with $A K T$ polymorphisms was then analyzed, revealing no association of the polymorphisms with the risks of lung cancer (Table 3). The association of the polymorphisms with the risk of lung cancer was further examined after stratifying the subjects according to gender and smoking status. However, the subsequent analysis revealed no significant association. Furthermore, the haplotypes of the AKT2 polymorphisms were not associated with the risks of lung cancer in 3 alternative models (data not shown).

\section{Discussion}

$\mathrm{V}$-akt murine thymoma viral oncogene homolog (AKT) is a serine/threonine protein kinase that is activated by PI3K- $\alpha$ and mediates PI3L signaling [21]. A major recurrent mutation (Glu17Lys) in the AKT1 gene, which encodes protein kinase $B$, has been identified in several solid tumors, including breast, colon, and ovarian cancers [22]. Overall, the frequency of $A K T 1$ mutations in non-small cell lung carcinoma (NSCLC) is about 1\%, and they have only been identified in squamous cell carcinoma [23]. Also, mutations in the $A K T 2$ and $A K T 3$ genes are rare in several tumors, including lung cancer [15]. 
Table 3. Association between $A K T 2$ and $A K T 3$ promoter polymorphisms and the risk of lung cancer

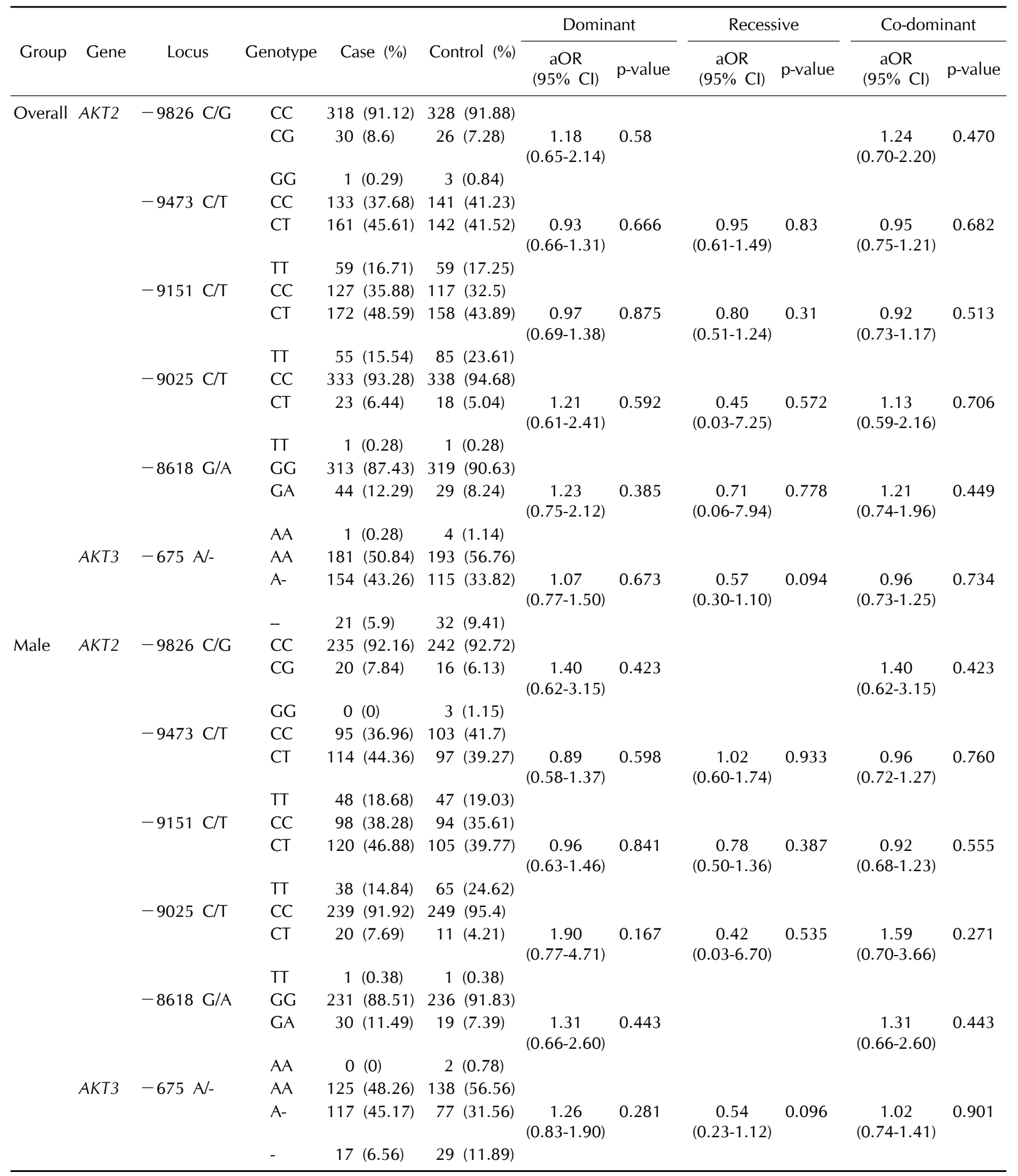


Table 3. Continued

\begin{tabular}{|c|c|c|c|c|c|c|c|c|c|c|c|}
\hline \multirow[b]{2}{*}{ Group } & \multirow[b]{2}{*}{ Gene } & \multirow[b]{2}{*}{ Locus } & \multirow[b]{2}{*}{ Genotype } & \multirow[b]{2}{*}{ Case $(\%)$} & \multirow[b]{2}{*}{ Control $(\%)$} & \multicolumn{2}{|c|}{ Dominant } & \multicolumn{2}{|c|}{ Recessive } & \multicolumn{2}{|c|}{ Co-dominant } \\
\hline & & & & & & $\begin{array}{c}\mathrm{aOR} \\
(95 \% \mathrm{Cl})\end{array}$ & $p$-value & $\begin{array}{c}\mathrm{aOR} \\
(95 \% \mathrm{Cl})\end{array}$ & $p$-value & $\begin{array}{c}\mathrm{aOR} \\
(95 \% \mathrm{Cl})\end{array}$ & $p$-value \\
\hline \multirow[t]{18}{*}{ Female } & AKT2 & $-9826 \mathrm{C} / \mathrm{G}$ & $\mathrm{CC}$ & $83(88.3)$ & 86 (89.58) & & & & & & \\
\hline & & & CG & $10(10.64)$ & $10(10.42)$ & $\begin{array}{c}1.06 \\
(0.41-2.73)\end{array}$ & 0.906 & & 0.991 & $\begin{array}{c}1.14 \\
(0.47-2.77)\end{array}$ & 0.768 \\
\hline & & & GG & 1 (1.06) & $0(0)$ & & & & & & \\
\hline & & $-9473 \mathrm{C} / \mathrm{T}$ & $\mathrm{CC}$ & $38(39.58)$ & $38(40)$ & & & & & & \\
\hline & & & $\mathrm{CT}$ & 47 (48.96) & $45(47.37)$ & $\begin{array}{c}1.10 \\
(0.60-2.04)\end{array}$ & 0.760 & $\begin{array}{c}1.02 \\
(0.41-2.56)\end{array}$ & 0.960 & $\begin{array}{c}1.06 \\
(0.67-1.67)\end{array}$ & 0.803 \\
\hline & & & TT & $11(11.46)$ & $12(12.63)$ & & & & & & \\
\hline & & $-9151 \mathrm{C} / \mathrm{T}$ & $\mathrm{CC}$ & $29(29.59)$ & 23 (23.96) & & & & & & \\
\hline & & & $\mathrm{CT}$ & $52(53.06)$ & $53(55.21)$ & $\begin{array}{c}0.78 \\
(0.40-1.52)\end{array}$ & 0.466 & $\begin{array}{c}0.79 \\
(0.36-1.71)\end{array}$ & 0.550 & $\begin{array}{c}0.83 \\
(0.53-1.29)\end{array}$ & 0.405 \\
\hline & & & TT & $17(17.35)$ & $20(20.83)$ & & & & & & \\
\hline & & $-9025 \mathrm{C} / \mathrm{T}$ & $\mathrm{CC}$ & 94 (96.91) & $89(92.71)$ & & & & & & \\
\hline & & & $\mathrm{CT}$ & $3(3.09)$ & 7 (7.29) & $\begin{array}{c}0.39 \\
(0.09-1.61)\end{array}$ & 0.192 & & & $\begin{array}{c}0.39 \\
(0.09-1.61)\end{array}$ & 0.192 \\
\hline & & & TT & $0(0)$ & $0(0)$ & & & & & & \\
\hline & & $-8618 \mathrm{G} / \mathrm{A}$ & GG & 82 (84.54) & $83(87.37)$ & & & & & & \\
\hline & & & GA & $14(14.43)$ & $10(10.53)$ & $\begin{array}{c}1.17 \\
(0.50-2.74)\end{array}$ & 0.718 & $\begin{array}{c}0.50 \\
(0.04-5.74)\end{array}$ & 0.575 & $\begin{array}{c}1.05 \\
(0.51-2.17)\end{array}$ & 0.897 \\
\hline & & & AA & 1 (1.03) & $2(2.11)$ & & & & & & \\
\hline & AKT3 & $-675 \mathrm{~A} /-$ & AA & $56(57.73)$ & 55 (57.29) & & & & & & \\
\hline & & & A- & 37 (38.14) & 38 (39.58) & $\begin{array}{c}0.92 \\
(0.50-1.67)\end{array}$ & 0.778 & $\begin{array}{c}1.02 \\
(0.21-5.03)\end{array}$ & 0.984 & $\begin{array}{c}0.94 \\
(0.56-1.56)\end{array}$ & 0.811 \\
\hline & & & - & $4(4.12)$ & $3(3.13)$ & & & & & & \\
\hline \multirow[t]{18}{*}{ Smoker } & $A K T 2$ & $-9826 \mathrm{C} / \mathrm{G}$ & $\mathrm{CC}$ & $226(92.24)$ & 119 (95.2) & & & & & & \\
\hline & & & CG & $19(7.76)$ & $6(4.8)$ & $\begin{array}{c}1.60 \\
(0.61-4.20)\end{array}$ & 0.337 & & & $\begin{array}{c}1.60 \\
(0.61-4.20)\end{array}$ & 0.337 \\
\hline & & & GG & $0(0)$ & $0(0)$ & & & & & & \\
\hline & & $-9473 \mathrm{C} / \mathrm{T}$ & $\mathrm{CC}$ & $90(36.29)$ & $45(36.29)$ & & & & & & \\
\hline & & & $\mathrm{CT}$ & $115(46.37)$ & $53(42.74)$ & $\begin{array}{c}0.98 \\
(0.62-1.55)\end{array}$ & 0.935 & $\begin{array}{c}0.85 \\
(0.49-1.49)\end{array}$ & 0.572 & $\begin{array}{c}0.95 \\
(0.70-1.28)\end{array}$ & 0.720 \\
\hline & & & TT & $43(17.34)$ & $26(20.97)$ & & & & & & \\
\hline & & $-9151 \mathrm{C} / \mathrm{T}$ & $\mathrm{CC}$ & 95 (38.46) & 48 (37.8) & & & & & & \\
\hline & & & $\mathrm{CT}$ & 116 (46.96) & $56(44.09)$ & $\begin{array}{c}0.97 \\
(0.62-1.52)\end{array}$ & 0.885 & $\begin{array}{c}0.70 \\
(0.39-1.27)\end{array}$ & 0.239 & $\begin{array}{c}0.89 \\
(0.65-1.22)\end{array}$ & 0.476 \\
\hline & & & TT & $36(14.57)$ & $23(18.11)$ & & & & & & \\
\hline & & $-9025 \mathrm{C} / \mathrm{T}$ & $\mathrm{CC}$ & 229 (91.6) & $122(97.6)$ & & & & & & \\
\hline & & & CT & $20(8)$ & $2(1.6)$ & $\begin{array}{c}3.36 \\
(0.98-11.54)\end{array}$ & 0.055 & $\begin{array}{c}0.40 \\
(0.03-6.44)\end{array}$ & 0.517 & $\begin{array}{c}2.35 \\
(0.82-6.76)\end{array}$ & 0.113 \\
\hline & & & TT & $1(0.4)$ & $1(0.8)$ & & & & & & \\
\hline & & $-8618 \mathrm{G} / \mathrm{A}$ & GG & $222(88.1)$ & 116 (92.06) & & & & & & \\
\hline & & & GA & 30 (11.9) & $10(7.94)$ & $\begin{array}{c}1.43 \\
(0.67-3.07)\end{array}$ & 0.356 & & & $\begin{array}{c}1.43 \\
(0.67-3.07)\end{array}$ & 0.356 \\
\hline & & & AA & $0(0)$ & $0(0)$ & & & & & & \\
\hline & AKT3 & $-675 \mathrm{~A} /-$ & AA & $120(48)$ & 71 (56.35) & & & & & & \\
\hline & & & A- & 114 (45.6) & 39 (30.95) & $\begin{array}{c}1.44 \\
(0.93-2.23)\end{array}$ & 0.105 & $\begin{array}{c}0.48 \\
(0.23-1.02)\end{array}$ & 0.055 & $\begin{array}{c}1.07 \\
(0.76-1.51)\end{array}$ & 0.682 \\
\hline & & & - & $16(6.4)$ & $16(12.7)$ & & & & & & \\
\hline
\end{tabular}


Table 3. Continued

\begin{tabular}{|c|c|c|c|c|c|c|c|c|c|c|c|}
\hline \multirow[b]{2}{*}{ Group } & \multirow[b]{2}{*}{ Gene } & \multirow[b]{2}{*}{ Locus } & \multirow[b]{2}{*}{ Genotype } & \multirow[b]{2}{*}{ Case $(\%)$} & \multirow[b]{2}{*}{ Control $(\%)$} & \multicolumn{2}{|c|}{ Dominant } & \multicolumn{2}{|c|}{ Recessive } & \multicolumn{2}{|c|}{ Co-dominant } \\
\hline & & & & & & $\begin{array}{c}\mathrm{aOR} \\
(95 \% \mathrm{Cl})\end{array}$ & p-value & $\begin{array}{c}\text { aOR } \\
(95 \% \mathrm{Cl})\end{array}$ & $p$-value & $\begin{array}{c}\mathrm{aOR} \\
(95 \% \mathrm{Cl})\end{array}$ & p-value \\
\hline \multirow[t]{18}{*}{ Non-smoker } & AKT2 & $-9826 \mathrm{C} / \mathrm{G}$ & $\mathrm{CC}$ & 87 (88.78) & 128 (88.28) & & & & & & \\
\hline & & & CG & $10(10.2)$ & $17(11.72)$ & $\begin{array}{c}0.97 \\
(0.43-2.18)\end{array}$ & 0.947 & & 0.991 & $\begin{array}{c}1.06 \\
(0.50-2.27)\end{array}$ & 0.875 \\
\hline & & & GG & $1(1.02)$ & $0(0)$ & & & & & & \\
\hline & & $-9473 \mathrm{C} / \mathrm{T}$ & $\mathrm{CC}$ & $39(40.21)$ & $52(36.36)$ & & & & & & \\
\hline & & & $\mathrm{CT}$ & $43(44.33)$ & $72(50.35)$ & $\begin{array}{c}0.85 \\
(0.50-1.45)\end{array}$ & 0.556 & $\begin{array}{c}1.15 \\
(0.55-2.40)\end{array}$ & 0.712 & $\begin{array}{c}0.96 \\
(0.65-1.40)\end{array}$ & 0.818 \\
\hline & & & TT & $15(15.46)$ & 19 (13.29) & & & & & & \\
\hline & & $-9151 \mathrm{C} / \mathrm{T}$ & $\mathrm{CC}$ & $30(30.3)$ & $45(31.03)$ & & & & & & \\
\hline & & & $\mathrm{CT}$ & $52(52.53)$ & $73(50.34)$ & $\begin{array}{c}1.09 \\
(0.62-1.91)\end{array}$ & 0.773 & $\begin{array}{c}0.92 \\
(0.47-1.81)\end{array}$ & 0.816 & $\begin{array}{c}1.01 \\
(0.70-1.45)\end{array}$ & 0.950 \\
\hline & & & TT & $17(17.17)$ & $27(18.62)$ & & & & & & \\
\hline & & $-9025 \mathrm{C} / \mathrm{T}$ & $\mathrm{CC}$ & $96(96.97)$ & $133(91.72)$ & & & & & & \\
\hline & & & $\mathrm{CT}$ & $3(3.03)$ & 12 (8.28) & $\begin{array}{c}0.35 \\
(0.10-1.28)\end{array}$ & 0.114 & & & $\begin{array}{c}0.35 \\
(0.10-1.28)\end{array}$ & 0.114 \\
\hline & & & $\mathrm{TT}$ & $0(0)$ & $0(0)$ & & & & & & \\
\hline & & $-8618 \mathrm{G} / \mathrm{A}$ & GG & $85(85.86)$ & $125(86.81)$ & & & & & & \\
\hline & & & GA & $13(13.13)$ & $17(11.81)$ & $\begin{array}{c}1.11 \\
(0.52-2.33)\end{array}$ & 0.792 & $\begin{array}{c}0.74 \\
(0.07-8.29)\end{array}$ & 0.806 & $\begin{array}{c}1.06 \\
(0.55-2.04)\end{array}$ & 0.871 \\
\hline & & & $\mathrm{AA}$ & $1(1.01)$ & $2(1.39)$ & & & & & & \\
\hline & AKT3 & $-675 \mathrm{~A} /-$ & $\mathrm{AA}$ & $58(59.18)$ & 73 (51.05) & & & & & & \\
\hline & & & A- & $36(36.73)$ & 64 (44.76) & $\begin{array}{c}0.72 \\
(0.42-1.20)\end{array}$ & 0.206 & $\begin{array}{c}0.91 \\
(0.25-3.35)\end{array}$ & 0.888 & $\begin{array}{c}0.77 \\
(0.50-1.21)\end{array}$ & 0.255 \\
\hline & & & - & $4(4.08)$ & $6(4.2)$ & & & & & & \\
\hline
\end{tabular}

Adjusted odds ratio (aOR) and p-values were calculated by unconditional logistic regression, adjusted for age, gender, and smoking history.

Logistic regression models were used to calculate the aORs, 95\% confidence intervals (Cls), and the corresponding p-values of co-dominant (minor allele homozygotes vs. heterozygotes vs. major allele homozygotes), dominant (minor allele homozygotes + heterozygotes vs. major allele homozygotes), and recessive (minor allele homozygotes vs. heterozygotes + major allele homozygotes) models after controlling for age, gender, and smoking status.

Recently, several polymorphisms in the AKT1 gene have been reported in relation to human disease [24-26]. Kim et al. [20] first reported that the $A K T 1$ polymorphisms could be used as prognostic markers for patients with early-stage NSCLC. However, there has been no study on the association between lung cancer risk and polymorphisms of AKT2 and AKT3. In this study, we investigated the association between $A K T 2$ and $A K T 3$ polymorphisms and the risk of lung cancer in the Korean population. The genotypes and haplotypes of the AKT2 and AKT3 genes were determined in 720 Koreans to evaluate the role of the AKT2 and AKT3 polymorphisms in the risk of lung cancer; however, the results revealed no significant difference between lung cancer patients and normal controls. Also, by TFSEARCH (version 1.3) analysis of the AKT2 and AKT3 polymorphism regions, the location of these variants did not have sequences for transcription factor binding sites. This result suggests that polymorphisms of the $A K T 2$ and $A K T 3$ promoter region are unlikely to play an important role in the susceptibility to lung cancer.

Polymorphisms often show ethnic variation [6, 27]. In the present study, we observed the frequencies of 5 polymorphisms in the AKT2 promoter region, and we observed frequencies of 3 polymorphisms in the AKT3 promoter region in 24 Korean populations using direct sequencing. In the direct sequencing result, we detected no frequencies in another known polymorphisms (AKT2: rs11666690, rs11665880, rs35814223, rs34408497, rs35408040, rs10418387; AKT3: rs11588441, rs6679386, rs41267521). The frequencies of $A K T 2$ promoter polymorphisms showed similar frequencies in the Asian ethnic groups (Han Chinese and Japanese) of the dbSNP database (www.ncbi.nlm.nih. gov/SNP). The frequency of the minor allele of rs35835614 in the AKT3 gene was 0.275; however, the frequency of this polymorphism has not been reported in the dbSNP database (www.ncbi.nlm.nih.gov/SNP). A series of our previous studies showed that polymorphisms of oncogenes, tumor suppressor genes, and receptor tyrosine kinases are related 
to lung cancer risk [6, 28, 29]. Recently, we reported that STK11 and PIK3CA polymorphisms are not related to genetic susceptibility to lung cancer $[30,31]$. The genotypes of the AKT2 and AKT3 promoter polymorphisms, determined in 720 Koreans in the present study, revealed no significant difference between lung cancer patients and normal controls. To our best knowledge, this is the first study on the association of AKT2 and AKT3 promoter polymorphisms and the risk of lung cancer in a Korean population.

\section{Acknowledgments}

This study was supported by the Korea Healthcare Technology R\&D Project, Ministry of Health, Welfare and Family Affairs, Republic of Korea (Grant No. A010250).

\section{References}

1. Jung KW, Park S, Kong HJ, Won YJ, Lee JY, Park EC, et al. Cancer statistics in Korea: incidence, mortality, survival, and prevalence in 2008. Cancer Res Treat 2011;43:1-11.

2. Schiller JH, Harrington D, Belani CP, Langer C, Sandler A, Krook J, et al. Comparison of four chemotherapy regimens for advanced non-small-cell lung cancer. N Engl J Med 2002;346: 92-98.

3. Devouassoux G, Pison C, Drouet C, Pin I, Brambilla C, Brambilla E. Early lung leukocyte infiltration, HLA and adhesion molecule expression predict chronic rejection. Transpl Immunol 2001;8:229-236.

4. Cargill M, Altshuler D, Ireland J, Sklar P, Ardlie K, Patil N, et al. Characterization of single-nucleotide polymorphisms in coding regions of human genes. Nat Genet 1999;22:231-238.

5. Ramensky V, Bork P, Sunyaev S. Human non-synonymous SNPs: server and survey. Nucleic Acids Res 2002;30:3894-3900.

6. Sung JS, Han SG, Whang YM, Shin ES, Lee JW, Lee HJ, et al. Putative association of the single nucleotide polymorphisms in RASSF1A promoter with Korean lung cancer. Lung Cancer 2008;61:301-308.

7. Vivanco I, Sawyers CL. The phosphatidylinositol 3-kinase AKT pathway in human cancer. Nat Rev Cancer 2002;2: 489-501.

8. Brognard J, Clark AS, Ni Y, Dennis PA. Akt/protein kinase B is constitutively active in non-small cell lung cancer cells and promotes cellular survival and resistance to chemotherapy and radiation. Cancer Res 2001;61:3986-3997.

9. Coffer PJ, Jin J, Woodgett JR. Protein kinase B (c-Akt): a multifunctional mediator of phosphatidylinositol 3-kinase activation. Biochem J 1998;335(Pt 1):1-13.

10. Cantley LC, Neel BG. New insights into tumor suppression: PTEN suppresses tumor formation by restraining the phosphoinositide 3-kinase/AKT pathway. Proc Natl Acad Sci U S A 1999;96:4240-4245.

11. Di Cristofano A, Pandolfi PP. The multiple roles of PTEN in tumor suppression. Cell 2000;100:387-390.

12. Zinda MJ, Johnson MA, Paul JD, Horn C, Konicek BW, Lu ZH, et al. AKT-1, -2, and -3 are expressed in both normal and tumor tissues of the lung, breast, prostate, and colon. Clin Cancer Res 2001;7:2475-2479.

13. Shoji K, Oda K, Nakagawa S, Hosokawa S, Nagae G, Uehara Y, et al. The oncogenic mutation in the pleckstrin homology domain of AKT1 in endometrial carcinomas. Br J Cancer 2009; 101:145-148.

14. Hussain K, Challis B, Rocha N, Payne F, Minic M, Thompson $\mathrm{A}$, et al. An activating mutation of $A K T 2$ and human hypoglycemia. Science 2011;334:474.

15. Soung YH, Lee JW, Nam SW, Lee JY, Yoo NJ, Lee SH. Mutational analysis of AKT1, AKT2 and AKT3 genes in common human carcinomas. Oncology 2006;70:285-289.

16. Pao W, Girard N. New driver mutations in non-small-cell lung cancer. Lancet Oncol 2011;12:175-180.

17. Liu YC, Huang CL, Wu PL, Chang YC, Huang CH, Lane HY. Lack of association between AKT1 variances versus clinical manifestations and social function in patients with schizophrenia. J Psychopharmacol 2009;23:937-943.

18. Lee KY, Joo EJ, Jeong SH, Kang UG, Roh MS, Kim SH, et al. No association between $A K T 1$ polymorphism and schizophrenia: a case-control study in a Korean population and a metaanalysis. Neurosci Res 2010;66:238-245.

19. Hildebrandt MA, Yang H, Hung MC, Izzo JG, Huang M, Lin J, et al. Genetic variations in the PI3K/PTEN/AKT/mTOR pathway are associated with clinical outcomes in esophageal cancer patients treated with chemoradiotherapy. J Clin Oncol 2009;27:857-871.

20. Kim MJ, Kang HG, Lee SY, Jeon HS, Lee WK, Park JY, et al. AKT1 polymorphisms and survival of early stage non-small cell lung cancer. J Surg Oncol 2012;105:167-174.

21. Testa JR, Bellacosa A. AKT plays a central role in tumorigenesis. Proc Natl Acad Sci U S A 2001;98:10983-10985.

22. Carpten JD, Faber AL, Horn C, Donoho GP, Briggs SL, Robbins $\mathrm{CM}$, et al. A transforming mutation in the pleckstrin homology domain of AKT1 in cancer. Nature 2007;448:439-444.

23. Malanga D, Scrima M, De Marco C, Fabiani F, De Rosa N, De Gisi S, et al. Activating E17K mutation in the gene encoding the protein kinase $A K T 1$ in a subset of squamous cell carcinoma of the lung. Cell Cycle 2008;7:665-669.

24. Harris SL, Gil G, Robins H, Hu W, Hirshfield K, Bond E, et al. Detection of functional single-nucleotide polymorphisms that affect apoptosis. Proc Natl Acad Sci U S A 2005;102: 16297-16302.

25. Zai CC, Romano-Silva MA, Hwang R, Zai GC, Deluca V, Müller DJ, et al. Genetic study of eight AKT1 gene polymorphisms and their interaction with $D R D 2$ gene polymorphisms in tardive dyskinesia. Schizophr Res 2008;106: 248-252.

26. Ikeda M, Iwata N, Suzuki T, Kitajima T, Yamanouchi Y, Kinoshita Y, et al. Association of AKT1 with schizophrenia confirmed in a Japanese population. Biol Psychiatry 2004;56: 698-700.

27. Kim JH, Kim H, Lee KY, Choe KH, Ryu JS, Yoon HI, et al. Genetic polymorphisms of ataxia telangiectasia mutated affect lung cancer risk. Hum Mol Genet 2006;15:1181-1186.

28. Jo UH, Han SG, Seo JH, Park KH, Lee JW, Lee HJ, et al. The ge- 
netic polymorphisms of HER-2 and the risk of lung cancer in a Korean population. BMC Cancer 2008;8:359.

29. Choi HS, Lee Y, Park KH, Sung JS, Lee JE, Shin ES, et al. Single-nucleotide polymorphisms in the promoter of the CDK5 gene and lung cancer risk in a Korean population. J Hum Genet 2009;54:298-303.

30. Sung JS, Park KH, Kim ST, Seo JH, Shin SW, Kim JS, et al. No association between PIK3CA polymorphism and lung cancer risk in the Korean population. Genomics Inform 2010;8: 194-200.

31. Sung JS, Whang YM, Park KH, Ryu JS, Choi JG, Seo JH, et al. No association between promoter polymorphism of STK11 gene and lung cancer risk in the Korean population. Cancer Res Treat 2009;41:211-217. 